\title{
Coupling between antimony mobility and iron cycling in the environment
}

\author{
EDWARD D. BURTON ${ }^{1}$ KERSTIN HOCKMANN, ${ }^{2}$ NILOOFAR \\ KARIMIAN. $^{3}$
}

${ }^{1}$ Southern Cross University, Australia, ed.burton@scu.edu.au

${ }^{2}$ University of Bayreuth, Germany, kerstin.hockmann@unibayreuth.de

${ }^{3}$ Southern Cross University, Australia, niloofar.karimian@scu.edu.au.au

The environmental mobility of antimony ( $\mathrm{Sb}$ ) is strongly affected by interactions with iron ( $\mathrm{Fe}$ ) oxides. These phases can undego dynamic transformation and recrystallization processes in response to redox-dependent Fe cycling. Here we describe recent research on the behaviour and effects of co-associated $\mathrm{Sb}$ during (i) microbially-mediated reduction and transformation of ferrihydrite, (ii) abiotic Fe(II)-catalyzed transformation of ferrihydrite, and (iii) Fe(II)-catalyzed recrystallization of goethite. ${ }^{1,2}$

The $\mathrm{Fe}(\mathrm{II})$-catalyzed transformation of $\mathrm{Sb}(\mathrm{V})$-sorbed ferrihydrite - under both microbially-mediated and abiotic conditions - leads to rapid formation of goethite, lepidocrocite (at low Sb loadings) and feroxyhyte (at high $\mathrm{Sb}$ loadings). Formation of these secondary $\mathrm{Fe}(\mathrm{III})$ oxides is associated with significant decreases in $\mathrm{Sb}(\mathrm{V})$ mobility. Likewise, the $\mathrm{Fe}(\mathrm{II})$-catalyzed recrystallization of $\mathrm{Sb}(\mathrm{V})$ sorbed goethite, as quantified via isotope tracer experiments using ${ }^{57} \mathrm{Fe}$, also results in decreased $\mathrm{Sb}(\mathrm{V})$ mobility.

Shell fitting of Sb K-edge EXAFS spectra indicates that the decreases in $\mathrm{Sb}$ mobility are due to partial $\mathrm{Sb}(\mathrm{V})$ incorporation into the Fe(III) oxide structure. This occurs via partial heterovalent substitution of $\mathrm{Sb}(\mathrm{V})-\mathrm{O}$ octahredra for $\mathrm{Fe}(\mathrm{III})-\mathrm{O}$ octahedra, and likely protects $\mathrm{Sb}(\mathrm{V})$ against direct, short-term interactions with the aqueous-phase.

Our research shows that $\mathrm{Fe}(\mathrm{III})$ oxides are dynamic phases whose solid structure (not just the reactive surface) may be available for $\mathrm{Sb}(\mathrm{V})$ sorption via structural incorporation. It is also clear that $\mathrm{Sb}(\mathrm{V})$ itself plays an active role in controlling $\mathrm{Fe}(\mathrm{III})$ oxide transformation pathways and recrystallization rates.

References:

(1) Burton, E.D., Hockmann, K., Karimian, N., Johnston, S.G. (2019) Antimony mobility in reducing environments: The effect of microbial Fe(III) reduction and associated secondary mineralization. Geochim. Cosmochim. Acta 245, 278-289.

(2) Burton, E.D., Hockmann, K., Karimian, N. (2020) Antimony sorption to goethite: Effects of $\mathrm{Fe}(\mathrm{II})$-catalyzed goethite recrystallization. ACS Earth Space Chem. (In Press). 